\title{
Business Lures Employed by Malay Kelantanese Entrepreneurs
}

\author{
Mohd Nizam Sahad, Suhaila Abdullah, Atikullah Haji Abdullah and Shuhairimi Abdullah
}

\begin{abstract}
The foundation of a successful business is essentially the level of consumer response to a product or service offered. Entrepreneurs' abilitities to cater to their consumers' needs are one of their secrets to success. Hence, the objective of this study is to uncover the secrets of business success, particularly the business lures that have helped Kelantan entrepreneurs to popularise products or services they offer. A qualitative approach was used to analyse the interview data according to themes. The study found five factors which determined the business success of the selected Malay Kelantanese entrepreneurs. These factors were: they were persistent in asking for help from Allah, they strived to be approachable entrepreneurs, and they cultivated positive entrepreneurial virtues such as having an honourable personality, being creative, and innovative, as well as being bold in their marketing strategy. Although the findings are not representative of all Malay entrepreneurs in Malaysia, this study can, however, serve as a source of reference to encourage other entrepreneurs to emulate the business success of the selected entrepreneurs. Apart from that, it can encourage awareness among the Muslim entrepreneurs, about the importance of managing a business in accordance with the Islamic laws
\end{abstract}

\section{Introduction}

Entrepreneurship has long been acknowledged as a career option and has also been also given priority in various Malaysian government's policies [13]. One of the ministries in Malaysia, which plays a role in the development of Bumiputera entrepreneurs is the Ministry of Entrepreneur Development. It has a crucial role in producing entrepreneurs of high quality, potentiality, and ability to form the Commercial and Industrial Community (MPP), as envisaged in Vision 2020 [35].

Meanwhile, in the context of Islam, entrepreneurship is a form of worship to meet the needs of life that are balanced in terms of worldly and hereafter [30]. It is crucial to integrate spiritual elements in business activities because Islam, in essence, operates on the basis of encapsulating every aspect of life in its entirety, regardless of the profession and the way of life led by a person [44]. In fact, Prophet Muhammad SAW was renowned in the field of business, where he had followed his uncle, Abu Thalib in a trade convoy to Damascus, Syria from a young age of $12[8,10]$. Armed with a vast experience in business, Prophet Muhammad SAW had shown that entrepreneurship is a reputable and lucrative career which should be highly valued by the Muslims [1].

However, the process of building and strengthening a business is not a simple affair because today's entrepreneurs are faced with many challenges, such as shortage of capital,

\footnotetext{
* Corresponding author: nizamsahad@usm.my
} 
competition, technology, management, communication, changes in demands, and economic uncertainty $[45,15,42,36,48,35]$. Therefore, many entrepreneurs have suffered losses and were declared as bankrupts. The statistics recorded for the period of three years from 20062009 by the Malaysian Insolvency Department showed that a total of 4,067 entrepreneurs of the small and medium enterprises (SMEs) had experienced bankruptcy [14].

Nevertheless, there are also entrepreneurs who have succeeded in their business. Behind the success of their business, there are, of course, practices, measures, and a certain thinking paradigm based on the theories and concepts of conventional entrepreneurship as well as complying with the religion of Islam. Therefore, this study aims to uncover the secrets and lures that have shaped the success of several selected entrepreneurs.

\subsection{Business and Entrepreneurship in Islam}

Although business and entrepreneurship are recognised in Islam, Allah SWT forbids His followers from earning a living based on haram (prohibited) resources, as Allah SWT says in Surah an-Nisa' [4]:29;

Translation: O you who believe! Eat not up your property among yourselves in vanities: but let there be amongst you traffic and trade by mutual good-will: nor kill (or destroy) yourselves: for verily God has been to you Most Merciful! ('Ali, 2005, p. 90).

Every Muslim businessperson or entrepreneur should understand the restrictions of halal (permitted) and haram, and practice them in their business activities. Based on Osella and Osella's [37] point of view, entrepreneurs who practice the teachings of Islam have inscribed their specific business interests and practices into the rhetoric of the common good. In other words, the combination of material success with moral values is seen as an exemplary contemporary way of being a modern, moral Muslim [37]. According to Adas [3], Islamic entrepreneurs may not be different from any other entrepreneurs in terms of their desire to expand their business and increase their profits, but their strong adherence to an Islamic identity, through which they give meaning to their economic incentives and activities, simultaneously redefine their Islamic identity in relation to their business activities. This is what distinguishes them from others.

Besides that, in Islam, the ummah (people) is encouraged to be self-employed and to venture into entrepreneurship (Ab. Mumin \& Suhaili, [1] to earn a living, as contained in a hadith narrated by Al-Bazzar:

Rifa'ah bin Rafi' said that the Prophet Muhammad SAW was once asked; "What is the best means of livelihood?" And Prophet SAW answered, "A person working with his hands and every sale that is clean."

\subsection{Malay Kelantanese Business}

Seeking for a source of income through business and entrepreneurship has become common pursuits among the Malays in Kelantan. A review of the Kelantan history has shown that business activity is part of the traditional socio-economic patterns of the state of Kelantan, where the majority of its population is Malay [28]. According to Ilhaamie [18] a majority of the Malay Muslims in Kelantan venture into business, whether in a small or large scale.

The state of Kelantan has shown an outstanding development since 2009 with the presence of the trade industry, construction, consultation, manufacturing, property, and agriculture [4]. Up to 2013, there was a total of 2,075 businesspersons registered at the Malaysian Malay Business Chamber Kelantan (DPMMK) [5]. The rapid development of business and entrepreneurship in Kelantan is due to the government's efforts in 
encouraging and facilitating the Malays and Bumiputeras to venture into the business domain [28].

\subsection{Entrepreneurial Ethics in Islam}

Ethics can be defined as a theory, a set of values, moral standards, rules, and principles relating to the behaviour of individuals in a particular social group that allows them to determine good or bad, right or wrong [33]. Thus, ethics are guidelines in making judgments and decisions on various matters. Meanwhile, Islamic ethics are referred to as a moral character, which is guided by the values of Islam, such as faith, justice, and universal happiness [19].

Ethics in Islam is divided into two, that is, etiquette to Allah SWT (as a caliph and worshipper) and etiquette to humans (comradeship) [2]. According to Abuznaid [2] these ethics are fundamental to business success, both in this world and for the life hereafter. Abuznaid [2] defines the entrepreneurial ethics of Islam as a code of moral principles in business described in the al-Qur'an and as-Sunnah (legal ways of the Prophet SAW), such as righteousness, honesty, justice, patience, keeping promises, generous, responsible, humble, respecting others, and have $t a q$ 'wa (piety) to Allah SWT.

Meanwhile, Kalsom and Mohd Ismail [22] placed five principles of Islamic entrepreneurial ethics, namely honesty (in business communication), trust (in resource management), sincerity (in terms of looking after the needs and safety of the customers), comradeship (among partners and customers), and justice (to all parties, as in pricing).

Islamic entrepreneurial ethics should be chosen by Muslim entrepreneurs as a form of reaction to the era of rapid development, where human greed is clearly evident (Zen, 2014). Hence, humans are at this time, in dire need for guidance to lead them out of digression, as contained in the hadith narrated by Abu Huraira RA that the Prophet SAW said;

"A time will come upon the people when one will not care how one gains one's money, legally or illegally." (Al-Bukhari, 1994, p. 465, no. 988).

\subsection{Entrepreneurial Ethics in Islam}

According to Ahmad Zahiruddin [6], management is a part of the sub-systems in life that cannot be separated from religion. It is because the orientation and the ultimate goal of Muslims in every aspect of their lives are to achieve the contentment of Allah SWT, and this distinguishes the Islamic management from the conventional form of management that is merely sufficient to fulfill human needs and desires [6]. Bearing this in mind, the practices of managing a business should be aligned with the Islamic entrepreneurial ethics. The merging of entrepreneurial or business practices with Islamic values, principles and business ethics has brought forth the Islamic entrepreneurial practices [19].

In managing a business, an entrepreneur should always monitor and plan with care so that every programme can be carried out smoothly. In fact, the quality and excellent performance in accomplishing any work is an emphasis in Islam [21], as contained in the hadith narrated by al-Bayhaqi RA in which the Prophet SAW said;

"Allah, the Almighty wants that when one of you does a job, he or she does it well." (Chapter 4, No. 5312)

Moreover, an entrepreneur should offer halal products or services to customers. Business activities which are clearly prohibited in Islam include to sell goods deemed to be harmful to others, such as alcohol, drugs, and prostitution; to take usury (interest); to practice unjust competition, and to practice fraud and forgery in business [49]. Hence, Allah SWT has called upon the human beings to earn a living based on halal sources, as Allah SWT says in Surah al-Baqarah [2]:172; 
Translation: O you who believe! Eat of the good things that We have provided for you, and be grateful to God, if it is Him you worship. ('Ali, 2005, p. 44)

The purpose of such practices is to purify the human souls so that they will be rewarded in this life and in the hereafter. When Muslims do good deeds, they will be rewarded equitably, as Ilhaamie (2014) states that such practices will bring blessings to entrepreneurs. Thus, according to Ibn Khaldun (1995), the foundation of Islamic management is irasati ad-din wa siyasatun dunya bih (putting religion at the highest place and lead the world with it).

\section{Methodology}

The study employs a qualitative approach, in which, 10 successful Malay Kelantanese entrepreneurs were selected for an interview. The Malay Kelantanese entrepreneurs were selected for this study because a majority of the Malay Muslims in Kelantan venture into business, whether in a small-scale or large-scale (Ilhaamie, 2014). The interview transcriptions were translated from Bahasa Melayu to the English language, and then, analysed from the perspective of how the Islamic entrepreneurship was carried out. In addition, a literature review was conducted to enable resources and data from documents, such as books, journals, manuscripts, and so forth about the cultures and practices of entrepreneurship to be used.

\section{Results and Discussion}

According to the Oxford Advanced Learner's Dictionary (2007), an entrepreneur can be defined as a person who makes money by starting or running businesses, especially when this involves taking financial risks (Hornby, 2010, p. 509). Ashmore (1989) defines entrepreneurs as individuals who run their own businesses. Meanwhile, Nor Aini Idris (2003) and Wim Naude (2010) consider entrepreneurs as a group of businesspersons and dealers who are willing to take risks, always strive for innovation, and smart, as well as creative in finding ways to increase wealth, power, and social status. Van Gelderen (2007) defines entrepreneurial skills as the ability that is translated into the behaviour or actions of an entrepreneur. These skills include the capability to start a new business, taking care of business, making decisions, identifying opportunities, managing time, communicating well, solving problems creatively, and managing stress, all of which are regarded as basic skills in business management (Soaib Asimiran \& Rosnani Jusoh, 2008).

Meanwhile, in Pihie, Akmaliah, and Elias' (2004) study, 11 main features of entrepreneurs were identified and they are: having high commitment, determination and perseverance, motivated to succeed and thrive, oriented to opportunities and goals, good at taking initiative and responsibility, skilful in problem solving, realistic, smart in searching and using feedbacks, possess internal control locus (highly confident of their capabilities to reach success), willing to take risks, not overly expecting power and high status, and with the integrity of reliability.

From the Western perspective, the main purpose of an entrepreneur setting up a business is to maximise profits, while continuously strive to expand the business (Longenecker et al., 2006; Madura, 2007; Scarborough \& Zimmerer, 2006). However, from the perspective of Islam, entrepreneurs who apply the values of Islam and take actions based on the Islamic ethics will be able to overcome the obstacles in business and at the same time, be able to bring themselves closer to the Creator. According Nor'Azzah (2009), among the main factors that lead to entrepreneurial success and gaining a huge profit in business is working hard and implementing Islamic ethics in conducting business. 
Previous research have shown that successful entrepreneurs have indeed adopted certain practices, such as conducting majlis tahlil (prayer ceremony) and doa selamat (safe prayer or supplication), and giving alms (Soaib Asimiran \& Rosnani Jusoh, 2008). Meanwhile, there are also a handful of entrepreneurs who use talisman, amulets, ibu duit (mystical way to 'breed' money), and wafak (a branch of hikmah (supernatural) knowledge, in which there are practices of using verses of the Al-Qur'an and Asmaul Husna (the best 99 names of Allah SWT)) as mystical business lures to the detriment of the Islamic aqidah (faith) and leads to sin by associating Allah SWT with other forms or beings (Mohd Nizam, 2015).

Entrepreneurs who manage their business based on the Islamic ethics will receive considerable amount of goodness and blessings. In other words, their work performance improves as a result of their beliefs that success, prosperity, and security actually depends entirely on Allah SWT, and an improvement in terms of confidence, optimism, perseverance, contentment, gratitude, and patience to face any outcome after performing a task in earnest (Isa Mohammed, Zulkarnain, \& AAhad, 2011). Indeed, righteous entrepreneurs will be guided in all matters, and the value of sincerity within them will be radiated (Isa Mohammed, Zulkarnain, \& AAhad, 2011), so that they will be rewarded with a high position and rank close to Allah SWT, as contained in the hadith narrated by Abu Sa'id RA that the Prophet SAW said;

"The truthful, trustworthy merchant is with the Prophets, the truthful, and the martyrs." (AtTirmidhi, 2007, p. 24, No. 1209)

After reviewing, researching, and analysing the interviews conducted with 10 selected successful Malay entrepreneurs of Kelantanese descent for this study, the identifiable practices and secrets of their success include instilling the love of being charitable and generous to anyone, whether they are customers or non-customers; perform sunnah (supererogatory) prayers, such as tahajjud (falls between the prayer times of the isha'a (night-time obligatory daily prayer) prayers and the fajr (dawn time obligatory daily prayer) prayers), hajaat (the prayer of need), and dhuha (morning prayer; begins after sunrise and ends at meridian); allocating time and taking the opportunity to supplicate in seeking for help and sustenance from Allah SWT; and readiness to extend help to anyone. Meanwhile, other factors which also contribute to their success in business include producing creative and innovative products in the market and strengthening their promotions and marketing strategies. The following are the examples of the interviews and discussions based on the source of Al-Qur'an, hadith, and other contemporary sources.

\section{Generosity and friendliness}

Respondent A, who has been running her own food store for nearly seven years in the city of Pasir Puteh, Kelantan, said;

"As businessmen and businesswomen, we have to be friendly, generous, and avoid being stingy. That is the key to our success in business, of which, at the same time, make us feel loved and are remembered by customers.

Generous and hospitable attitude, which are the opposite of parsimonious and arrogance, are good values in Islam and they bring blessings in business, as mentioned by Allah SWT in Surah al-Layl [92]:8-11;

Translation: But he who is a greedy miser and thinks himself self-sufficient, And gives the lie to the Best,- We will indeed make smooth for him the path to Misery; Nor will his wealth profit him when he falls headlong (into the Pit). ('Ali, 2005, p. 653) 


\section{Perform supererogatory prayers}

According to Respondent B, the success in her business was due to her reliance on Allah SWT, and thus, she sought help only from Allah SWT. She advised other entrepreneurs to perform prayers for the love of Allah SWT, as a sign of their gratefulness, and not simply because they needed something. In other words, every form of worship should be performed sincerely to gain mardhatillah (the pleasure of Allah SWT), as mentioned by Allah SWT in Surah al-Bayyinah [98]:5;

Translation: And they have been commanded no more than this: to worship God, offering Him sincere devotion, being true (in faith); to establish regular prayer; and to practise regular charity; and that is the Religion Right and Straight. ('Ali, 2005, p. 662)

Moreover, entrepreneurs are encouraged to read the Qur'an to find inner peace, as well as getting the rewards promised by Allah SWT, as mentioned in a hadith narrated by Imam Abu Dawud Sulayman ibn al-Ash'ath as-Sijistani RA (Book 8, Hadith No. 41), which means;

'Uqbah bin 'Amir al-Juhani said: When we were in the Suffah, the Messenger of Allah SAW asked: "Which of you would like to go out every morning to Buthan or Al-'Aqiq and bring two large humped and fat she-camels without being guilty of sin and severing ties of relationship?" They (the people) said: "Messenger of Allah, we would all like that." He said: "If any one of you goes out in the morning to the mosque and learns two verses of the Book of Allah, the Exalted, it is better for him than two she-camels, and three verses are better for him than three she-camels, and so on than their numbers in camels."

One respondent expressed her opinion regarding the practice of reciting the Qur'an:

"Verses of the Qur'an should be frequently read because it is necessary to be istiqamah (consistent) and constant in every practice so that they are well instilled within us. Not to just reading the Qur'an, hoping for rewards from Allah or that Allah fulfils our dreams and desires. No such thing! In reading and implementing such practices, they have to be parallel with our intention to gain the pleasure of Allah, and not in hoping for worldly rewards. InsyaAllah (God willing), only then will Allah bestow what is best for us. Allah would not simply give us what we ask for."

The rewards from Allah SWT to His servants who perform religious duties and practices are not necessarily in terms of material gains, but they may also be in terms of inner strength, such as happiness and tranquillity. Thus, a Muslim should submit (tawakkal) to Allah SWT and trust that indeed, Allah's arrangement is the best, as stated by Allah SWT in Surah al-Baqarah [2]:216;

Translation: But it is possible that you dislike a thing which is good for you, and that you love a thing which is bad for you. But God knows, and you know not. ('Ali, 2005, p. 50)

Respondent $\mathrm{C}$, who owns a mixed rice food store who runs three outlets, believed that by performing supererogatory prayers, the relationship between the slave and his/her Creator will be firm and steady, as mentioned in her statement;

"There is no specific practice, but the thing which I never forget is performing tahajjud and dhuha supererogatory prayers. I am obliged to perform them. Not only because I want an abundant of sustenance, but that is the way I draw closer to Allah, to connect with Him."

\section{Familiarise with supplication in every affair}


Among the $d u^{\prime} a$ (supplication) practiced by some respondents are Surah al-Fatihah and alWaqi' ah as an opening of store $d u^{\prime} a$, whereby, they are steadfast in reading these surahs, as excerpted from the statements of Respondent $\mathrm{D}$ and $\mathrm{E}$;

"Once I reach the store, I start off by reading Surah al-Fatihah from the beginning until the end. Therefore, I try not to be late otherwise I will be in a hurry till it becomes slipshod and easy to forget, and that my mouth will be locked from reading the $d u$ 'a."

Meanwhile, respondent E reads Surah al-Waqi'ah as a $d u^{\prime} a$ before he opens his shop, as mentioned in his statement;

"Previously, there was an Ustaz (religious teacher) who taught me to practise reading up Surah al-Waqi'ah till the end before opening the store. It is believed that by reading Surah al-Waqi'ah as an opening of the store's $d u^{\prime} a$, the store will be shielded from treasonous sorcery of others and it is also able to popularise the business."

The following is the answer of Respondent $\mathrm{E}$ when asked about the impact of forsaking the recitation of Surah al-Waqi'ah:

"If we do not read it, our store will be easily inflicted with treasonous sorcery, causing customers not to see our store. Since we are running our business in an open space, where there are many others who are engaged in business, there is a possibility of others to be jealous of us. Then, they would go see a shaman to ask for something or seek for help to bring us down, for treason. If you do not have time to read it, you can just turn on the cassette."

In addition, there are also posters of surahs (any of the 114 chapters of the Al-Qur'an) found suspended and pasted on the walls of the stores of a number of respondents. According to a respondent, the purpose of the suspension of these surahs is not merely to popularise the business, since all sustenance and blessings come from Allah SWT. In other words, a business can only be successful with the help of Allah SWT. Thus, the practice of reading or even suspending surahs is a kind of effort and endeavour to seek the help and pleasure of Allah SWT. According to the respondent as well, the suspension of these surahs will be able to remind them of Allah SWT in times of negligence.

\section{Produce creative and innovative products or services in the market}

According to Shuhairimi (n.d.), innovation and creativity are necessary skills for every entrepreneur. Creative skill is the key factor which distinguishes one entrepreneur after another. In fact, Allah SWT has bestowed a variety of sources to complement human needs. However, on a general scale, the endowment will not be able to accommodate the needs of a man if the optimal results are not manipulated as maximal as possible [27]. Therefore, entrepreneurs will have to bring out the creative and innovative values from within themselves in order to meet the diverse needs and desires of the communities.

Luecke and Katz [25] defined innovation as the introduction of a substance or method in which it is an image, a combination or synthesis of knowledge that exists in the natural state, has an interest and value to a product or process or a new service. According to Muhammad Hisham [31], a company does not necessarily produce the element of innovation only in the context of the creation of goods or services, but innovation can also exist in the form of new business models, such as the concept of a business franchise. Moreover, innovation can also exist in the marketing strategy, as some of the companies which offer services after office hours or on weekends. Meanwhile, businessmen and businesswomen in the Siti Khadijah Market, Kelantan choose to keep running their business on weekends. 
Creativity and innovation is described in a hadith of Prophet Muhammad SAW. It was narrated from Simak that he heard Musa bin Talhah bin 'Ubaidullah narrating that his father said;

"I passed by some palm trees with the Messenger of Allah SAW, and he saw some people pollinating the trees. He said: 'What are these people doing?' They said: 'They are taking something from the male part (of the plant) and putting it in the female part.' He said: 'I do not think that this will do any good.' News of that reached them, so they stopped doing it, and their yield declined. News of that reached the Prophet SAW and he said: 'That was only my thought. If it will do any good, then do it. I am only a human being like you, and what I think may be right or wrong. But When I tell you: "Allah (SWT) says," I will never tell lies about Allah (SWT)."” (Sunan Ibn Majah, Vol. 3, Book 16, Hadith No.2470)

\section{Strengthen the promotion and marketing}

The entrepreneurs should strive tenaciously and give emphasis to their marketing strategy. This is because a good product or service will not sell by itself without the effort to market, promote, and advertise it [39].

The respondents were of the view that the strategies and methods for introducing a product or service offered to customers play an important role in the smooth running of their business activities. The strategies and methods include strengthening their promotional activities, testimonials, and product marketing to gain consumers' trusts. For instance, Dato' Sri Dr. Vida expanded her product marketing by sponsoring the Kelantan football team and customising the team name from 'The Red Warriors' to 'Pamoga Qu Puteh The Red Warriors'. The decisions made by Dato' Sri Dr. Vida, as an entrepreneur, have shown her courage in marketing her products. This trait is in line with Nor Aini's (2003) statement that a smart entrepreneur is one who is able to seize economic opportunities, identify potential products, analyse potential markets and customers, and understand the desires and preferences of customers.

\section{Conclusion}

Based on the secrets of success in business, which have been shared by the respondents, it is apparent that the practices adopted were in accordance with the teachings of Islam and the sunnah of Prophet Muhammad SAW. The respondents' aim of adopting these practices is to popularise their business in an captivating way that is permitted in Islam, whilst drawing themselves closer to the Al-Khaliq (Creator). Thus, becoming an entrepreneur is a fardhu kifayah (obligatory acts which exist in the Islamic community regardless of who becomes one. However, Allah SWT does not require them to be accomplished by each person or some specific person, since the interests of the community can be realised through the efforts of a few who are morally responsible. Hence, it does not entail everyone to fulfill this obligation) and worship for sustenance. Meanwhile, in the process of popularising their business, there are surely certain techniques and practices which must be adopted by the entrepreneurs in order to attract the customers.

\section{Acknowledgement}

This study is funded by the short-term grant of Universiti Sains Malaysia (304/phumaniti/6313196), Penang. 


\section{References}

1. Ab. Mumin Ab. Ghani \& Suhaili Sarif, Penerapan budaya keusahawanan dalam masyarakat Islam. Paper presented at the Seminar Keusahawanan Islam Peringkat Kebangsaan, 6 September, Academy of Islamic Studies, Universiti Malaya, Kuala Lumpur, (2005)

2. Abuznaid, S.A., Business ethics in Islam: The glaring gap in practice. International Journal of Islamic and Middle Eastern Finance and Management, 2(4), 278-288, (2009)

3. Adas, E.B., The making of entrepreneurial Islam and the Islamic spirit of capitalism. Journal for Cultural Research, 10(2), 113-137(2006)

4. Ahmad, M., The influence of culture on Malay Muslim business practice: A case study of Malaysia with special reference to the state of Kelantan Dar al-Naim (Unpublished Ph.D thesis). University of Birmingham, UK, (2009)

5. Ahmad, M., Md. Hussain, M.N., Palil, R., \& Dolah, N.H., The Islamic image of market place in Malaysia: A case study presentation. SEA Journal of Contemporary Business, Economic and Law, 2(1), 86-88, (2013)

6. Ahmad Zahiruddin Mohd Zabidi, Hebatnya Rasulullah: Teladani peribadi dan pengurusan kekasih Allah. Shah Alam, Selangor: Karya Bestari@ @rup Buku Karangkraf Sdn. Bhd, (2014)

7. Al-Bukhari, Summarized sahih Al-Bukhari: Arabic-English (Compiled: AI.Z.A.A.L. Az-Zubaidi, Translated: M.M. Khan). Riyadh: Dar-us-Salam Publications, (1994)

8. Al-Buthy, M.S.R., Sirah Nabawiyah: Kajian mendalam manhaj gerakan Islam pada masa Rasulullah (s.a.w.) (Translated by: Aunur Rafiq Shaleh Tamhid). Shah Alam, Selangor: Pustaka Dini, (2005)

9. 'Ali, A.Y., The meaning of the holy Qur'an. Subang Jaya, Selangor: Secretariat for Asia Assembly of Ulama', (2005)

10. An-Nadwi, A.H.A., Riwayat hidup Rasulullah (Translated by: H. Bey Arifin \& Yunus Ali Muhdhar). Surabaya: PT Bina Ilmu, (2006)

11. Ashmore, M.C., The power of the entrepreneurial vision. Vocational Education Journal, 64(8), 28-29, (1989)

12. At-Tirmidhi, A.I.M.I.I., English translation of jami' At-Tirmidhi (Vol. 1) (Compiled: H.A.E.M.I.E. At-Tirmidhi, Translated: A. Khaliyl). Riyadh: Darussalam, (2007)

13. Azmi Abdul Manaf, Nik Hairi Omar \& Lee, K.Y, Faktor kritikal kejayaan usahawan dalam perniagaan. Journal of Social Sciences and Humanities, 7(1), 3445, . (2012)

14. Hansard Parliament, Pemberitahuan pertanyaan Dewan Rakyat Malaysia, Soalan 1, Bertarikh 27/10/2009. Retrieved from www.parlimen.gov.my/files/hindex/pdf/DR-27102009.pdf (accessed 1 November 2011), (2010)

15. Hess, D. W., Relevance of small business courses to management needs. Journal of Small Business Management. 25(1): 26-34, (1987)

16. Hornby, A.S., Oxford Advanced Learner's Dictionary ( $8^{\text {th }}$ ed.). Oxford: Oxford University Press, (2010)

17. Ibnu Khaldun, Muqaddimah (translated). Kuala Lumpur: Dewan Bahasa dan Pustaka, (1995)

18. Ilhaamie Abdul Ghani Azmi, The implementation of Islamic business practices of women traders: A study in an Islamic state in a developing country. GJAT, 4(2), $17-28,(2014)$ 
19. Ilhaamie Abdul Ghani Azmi \& Mohamed Dahlan Ibrahim, Wanita dan pelaksanaan amalan keusahawanan Islam: Satu kerangka konseptual. In the proceeding of International Conference on Islamic Management, 2013, Department of Shariah and Management, Academy of Islamic Studies, Universiti Malaya, Kuala Lumpur, (2009)

20. Isa Mohammed Adamu, Zulkarnain Kedah, \& Aahad Osman-Gani, Spirituality in entrepreneurship from Islamic perspective. A conceptual analysis on the effects on entrepreneurial motivation and social responsibility. Proceeding of the 10th International Conference of the Academy of HRD (Asia Chapter), 3-6 December 2011, Kuala Lumpur, (2011)

21. Jabnoun, Naceur, Islam and management. Kuala Lumpur: Institut Kajian Dasar, (1994)

22. Kalsom, A. \& Mohd. Ismail, Compliance to Islamic marketing practices among businesses in Malaysia, Journal of Islamic Marketing, 1(3), 286-297, (2010)

23. Kent, C.A., Integrating entrepreneurship in the secondary curriculum: Economics and other courses. In Kent, C.A. (Ed.), Entrepreneurship Education. Connecticut: Quorum Book, (1990)

24. Longenecker, J.G., Moore, C.W., Petty, J.W., \& Palich, L.E., Small business management: An entrepreneurial emphasis (13th ed.). Mason, $\mathrm{OH}$ : Thompson South-Western, (2006)

25. Luecke, R., \& Katz, R., Harvard business essentials: Managing creativity and innovation. Harvard: Harvard Business School Press, (2003)

26. Madura, J., Introduction to business (4th ed.). Mason, OH: Thompson SouthWestern,k (2007)

27. Maisarah Ahmad \& Suhaila Abdul Kadir, Characteristics of entrepreneurs and the practice of Islamic Values in influencing the success of small medium enterprises in Kelantan and Selangor. Journal of Social and Development Sciences, 4(5), 229, (2013)

28. Mohd Fauzi Yaacob, Peniaga dan perniagaan Melayu: Suatu kajian di Kota Baharu, Kelantan. Kuala Lumpur: Dewan Bahasa dan Pustaka, Kementerian Pelajaran, Malaysia, (1981)

29. Mohd Nizam Sahad, Penggunaan azimat pelaris perniagaan menurut perspektif akidah Islam. Melayu: Jurnal Antarabangsa Dunia Melayu, 8(1), 18-44, (2015)

30. Mohd Zain Mubarak, Asyraf Ab. Rahman \& Mohd Rafi Yaacob, Elemen kerohanian dalam keusahawanan Islam: Kajian terhadap usahawan berjaya di negeri Kelantan. Journal of Business and Social Development, 3(1), 43-53, (2015)

31. Muhammad Hisyam bin Mohamad, Membudayakan inovasi. Berita Harian, (2013)

32. Nor Aini Idris, Daya saing usahawan wanita Melayu menghadapi cabaran globalisasi. Paper presented at the Persidangan Kebangsaan Pusat Pengajian Sosial, Pembangunan \& Persekitaran (Cabaran Pembangunan Dilema Persekitaran), Universiti Kebangsaan Malaysia, (2003)

33. Nor'Azzah Kamri, Nilai dan etika dalam pengurusan Islam (Values and ethics in the management of Islam) (unpublished MA of Shariah dissertation). Department of Shariah and Management, Academy of Islamic Studies, Universiti Malaya, Kuala Lumpur, (2002)

34. Nor'Azzah Kamri, Etika usahawan muslim berpandukan kepada al-Quran dan alSunnah, In Keusahawanan Islam: Konsep dan isu-isu perlaksanaan. Universiti Malaya: Jabatan Syariah dan Pengurusan, Akademi Pengajian Islam, (2009)

35. Norasmah Othman, Keberkesanan program keusahawanan remaja di sekolah menengah (Ph.D dissertation). Universiti Putra Malaysia, Serdang, (2002) 
36. Norhashim Nordin, Towards strengthening SMIS. The Bank Pembangunan perspective. Paper presented at the 1st National Conference for SMIS, Kuala Lumpur, Malaysia, (1994)

37. Osella, F. \& Osella, C., Muslim entrepreneurs in public life between India and the Gulf: Making good and going good. Journal of the Royal Anthropological Institute, 15(1), 202-221, (2009)

38. Pihie, L., Akmaliah, Z., \& Elias, H., Keupayaan usahawan Bumiputera melaksanakan kemahiran keusahawanan: Satu kajian kes. Pertanika Journal of Social Sciences \& Humanities, 12(1), 61-70, (2004)

39. Sazelin Arif, Keupayaan pemasaran dalam kalangan pengusaha kecil makanan halal di Melaka Tengah: Satu kajian awal. Malim-Jurnal Pengajian Umum, 10 (2009), 183-208, (2009)

40. Scarborough, N.M. \& Zimmerer, T.W., Essentials of entrepreneurship and small business management. Upper Saddle River, New Jersey: Pearson/Prentice Hall, (2006)

41. Shuhairimi Abdullah (n.d.). Nilai Inovasi, Kreativiti Perlu Dalam Keusahawanan, Retrieved from http://mukmin.com.my/ ID 1163, Kategori 12.

42. Sieh, L.M.L., Malaysian industrial and entrepreneur profile. Malaysian Management Review, 25(2), 3-10, (1990)

43. Soaib Asimiran, S. \& Rosnani Jusoh, R., Membangunkan kemahiran generik usahawan Malaysia (KeGUM): Satu kajian kes ke atas usahawan makanan. Proceeding of the Seminar Kemahiran Insaniah dan Kesejahteraan Sosial (SKIKS) 2008. Penerbit Universiti Teknikal Melaka. ISBN: 978-983-2948-33-9, (2008)

44. Solahuddin Abdul Hamid \& Che Zarrina Sa'ari, Reconstructing entrepreneur's development based on al-Qur'an and al-Hadith. International Journal of Business and Social Science, 2(19), 110-116, (2011)

45. Timmons, J.A., Smollen, L.E., \& Dingee, A.L.M., New Venture Creation ( $2^{\text {nd }}$ ed.). Homewood, Illinois: Irwin, (1985)

46. Van Gelderen, M., Research based yet action oriented: Developing individual level enterprising competencies. Paper presented at the 17th Global Conference Internationalizing Entrepreneurship Education and Training, 8-11 July, 2007, Faculty of Management and Economics, Gdansk University of Technology, Gdansk, Poland, (2007)

47. Wim Naude, Promoting entrepreneurship in developing countries: Policy challenges. World Institute for Development Economics Research of the United Nations University (UNUWIDER) Policy Brief, 42010, 1-8, (2010)

48. Zaidatol Akmaliah, Lope Pihie, \& Habibah, Keusahawanan dan Motivasi Diri. Serdang: Penerbit Universiti Putra Malaysia, (1997)

49. Zen Abdul Rahman, Strategi pemasaran cara Rasulullah. Batu Caves, Selangor: Al-Hidayah House of Publishers Sdn. Bhd, (2014) 